the Vessel Register and only half of all on-water vessel and person hours. By contrast, full cabin cruisers comprised $4 \%$ of registered vessels, accounted for $6 \%$ and $8 \%$ of all vessel and person trips, respectively, and $13 \%$ and $18 \%$ of all vessel and person on-water hours, respectively. The proportion of total exposure on each measure was above expectations for half cabin cruisers, trailer sailers and yachts and below expectations for PWC. Fishing was the most popular activity, accounting for most trips (70\%), person trips (61\%), on-water vessel hours (66\%) and person hours $(57 \%)$ followed by pleasure cruising $(16 \%, 17 \%, 20 \%$ and $19 \%)$ towed water sports $(9 \%, 16 \%, 7 \%, 12 \%)$ and racing $(1 \%, 2 \%, 2 \%, 2 \%)$. These data will form the denominator to estimate marine incident and injury rates.

\title{
0674 EXPOSURE TO RISK IN RECREATIONAL POWER BOATING, VICTORIA, AUSTRALIA
}

E Cassell ${ }^{*}$ K Ashby Correspondence: Monash University Accident Research Centre, Accident Research Centre Building 70 Monash University Victoria 3800, Australia

\subsection{6/ip.2010.029215.674}

Exposure data, measured in vessel and person trips and vessel and person on-water hours, were collected prospectively in quarterly sample surveys of 1600 power recreational vessel owners in the year ended 30 September 2009 (a 1\% sample of registered vessels). The response rate was $49 \%$. Over the year, vessels took an estimated 913002 trips and 2.21 million person trips (6.0 trips and 14.6 person trips per vessel) and spent 5.68 million $h$ and 14.26 million person-h on the water $(37.5 \mathrm{~h}$ and 91.4 person $\mathrm{h}$ per vessel). Open boats comprised $71 \%$ of vessels and accounted for less trips and person trips $(62 \%)$ than expected given their representation on 